\title{
EFISIENSI PRODUKSI PAKAN ALAMI SECARA INTENSIF
}

\author{
Gede S. Sumiarsa dan Rina Astuti \\ Balai Besar Riset Perikanan Budidaya Laut \\ Jl. Br. Gondol, Kec. Gerokgak, Kab. Buleleng, Singaraja, Bali 81155 \\ E-mail: rimgdl@indosal.net.id
}

(Naskah diterima: 9 Agustus 2011; Disetujui publikasi: 28 Oktober 2011)

\begin{abstract}
ABSTRAK
Rotifer Brachionus rotundiformis merupakan pakan alami utama yang dipergunakan dalam perbenihan ikan-ikan laut. Produksi rotifer pada percobaan ini dilakukan dalam wadah kecil $\left(0,5 \mathrm{~m}^{3}\right)$ dengan padat penebaran awal 100-150 ekor/mL, diberikan fitoplankton Nannochloropsis oculata kepadatan tinggi $\left(1,0-2,0 \times 10^{8} \mathrm{sel} / \mathrm{mL}\right)$ didalam dan di luar ruangan. Oksigen murni dialirkan ke dalam bak- bak budidaya rotifer dengan laju 0,05-0,1 L/menit sedangkan penghitungan kepadatan fitoplankton, rotifer, dan pemeriksaan kualitas air dilakukan setiap hari. Rata- rata kepadatan akhir rotifer budidaya didalam ruangan pada hari hari ke 7- 9 adalah $525 \pm 6,1$ ekor/ $\mathrm{mL}$ sedangkan budidaya rotifer di luar ruangan hanya mampu berlangsung selama 2- 4 hari dengan kepadatan yang terus menurun setelah penebaran awal. Kandungan lemak rotifer adalah $14,0 \%$ dengan kandungan asam lemak DHA: 1,4 mg/g DW, EPA 57,2 mg/g DW, dan HUFA: 61,5 $\mathrm{mg} / \mathrm{g}$ DW dengan rasio DHA/ EPA 0,02. Suhu air, $\mathrm{pH}$, dan total amonium berturut- turut berkisar pada nilai $26,1^{\circ} \mathrm{C}-34,1^{\circ} \mathrm{C}, 8,3-8,8$ dan $0,48-2,20 \mathrm{mg} / \mathrm{L}$.
\end{abstract}

KATA KUNCl: Brachionus rotundiformis, indoor dan outdoor, Nannochloropsis oculata, pakan alami, rotifer

ABSTRACT: Improving efficiency in intensive live feed production. By: Gede S. Sumiarsa and Rina Astuti

Rotifer Brachionus rotundiformis is the main live feed used to feed marine fish in hatchery. Rotifer production in this trial was conducted in small $0.5 \mathrm{~m}^{3}$ fiberglass tanks with the average inital stocking density of 100-150 pcs $/ \mathrm{mL}$ fed with high density of marine chlorella Nannochloropsis oculata (1.0-2.0 $10^{8}$ cells $/ \mathrm{mL}$ ) both indoor and outdoor. Pure oxygen was flown into the rotifer tanks with the rate of 0.05-0.1 L/ minute. Counting of both phytoplankton and rotifers and water quality obervation were carried out daily. Average indoor final densities of rotifers on 7-9 days after

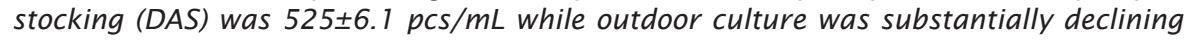
within 2-4 DAS. Lipid content of rotifer was $14 \%$ with DHA content of $1.4 \mathrm{mg} / \mathrm{g} D W, E P A$ $57.2 \mathrm{mg} / \mathrm{g}$ DW and HUFA: $61.5 \mathrm{mg} / \mathrm{g}$ DW DHA/EPA ratio of 0.02. Water temperature, $\mathrm{pH}$ and total ammonium were $26.1^{\circ} \mathrm{C}-34.1^{\circ} \mathrm{C}, 8.3-8.8$, and $0.48-2.2 \mathrm{mg} / \mathrm{L}$, respectively.

KEYWORDS: Brachionus rotundiformis, indoor and outdoor, live feed, Nannochloropsis oculata, rotifer 


\section{PENDAHULUAN}

Produksi massal pakan alami rotifer (Brachionus rotundiformis) dan fitoplankton Nannochloropsis oculata secara massal dalam hatcheri ikan laut walaupun murah tetapi sering tidak dapat diandalkan (unreliable) (Fulks \& Main, 1992) padahal pakan alami merupakan salah satu faktor penting dalam produksi benih ikan-ikan laut. Salah satu faktor yang diduga menyebabkan rendahnya keandalan produksi pakan alami adalah tingkat intensifikasi sistem produksinya yaitu produksi semi-continuous system yang menghasilkan kepadatan akhir yang relatif rendah (Yoshida, 1992) dibandingkan dengan sistem produksi batch culture dan recycled culture. Oleh sebab itu, tingkat sistem produksi massal pakan alami dalam hatcheri mutlak ditingkatkan lebih intensif lagi agar dapat mendukung produksi massal ikan-ikan laut.

Rotifer telah umum dipergunakan sebagai pakan alami dalam hatcheri ikan-ikan laut karena produksi massalnya mudah dan sederhana (Witt et al., 1984; Araujo et al., 2001). Di samping itu, rotifer toleran terhadap perubahan lingkungan dan cepat pertumbuhannya dibandingkan dengan pakan alami nauplii copepoda walaupun kandungan nutrisi rotifer lebih rendah dibandingkan nauplii copepoda (Fukusho \& Hirayama, 1991; Su et al., 1997). Kekurangan nutrisi rotifer dapat ditingkatkan dengan pengkayaan dengan bahan- bahan pengkaya komersial (Craig et al., 1994).
Percobaan ini bertujuan untuk meningkatkan efisiensi teknik produksi massal rotifer melalui produksi lebih intensif untuk meningkatkan kepadatan rotifer dalam wadahwadah yang relatif kecil.

\section{BAHAN DAN METODE}

\section{Produksi Massal Fitoplankton $\boldsymbol{N}$. oculata dan Rotifer B. rotundiformis}

Produksi massal N. oculata dilakukan pada bak- bak beton di luar ruangan (outdoor) pada kelompok hatcheri Marine Seed Production (MSP), Multi Species Hatchery (MSH), dan hatcheri Utama (Main) dengan volume bervariasi antara 10-50 $\mathrm{m}^{3}$ dengan volume total $434 \mathrm{~m}^{3}$ (Tabel 1). Pemasukan air laut untuk produksi fitoplankton pada hatcheri MSP dan MSH melalui bak dan tangki saringan pasir (sand filter) pada hatcheri utama masih menggunakan saringan kantong (filter bag). Air laut yang telah tersaring ditampung dalam bak-bak yang bervolume terbesar pada masing- masing hatcheri, disterilisasi dengan klorine $200 \mathrm{mg} / \mathrm{L}$, diberi 6- 12 titik aerasi dengan laju $5 \mathrm{~L}$ / menit. Setelah 24 jam, air steril tersebut dinetralisir dengan $50 \mathrm{mg} / \mathrm{L}$ sodium thiosulfat $\left(\mathrm{Na}_{2} \mathrm{~S}_{2} \mathrm{O}_{3} \cdot 5 \mathrm{H}_{2} \mathrm{O}\right)$, dipompa ke dalam bak- bak lainnya untuk memulai siklus produksi massal fitoplankton. Dosis pupuk pertanian untuk produksi fitoplankton berbeda pada setiap hatcheri dan dicantumkan dalam Tabel 2.

Inokulasi dilakukan dari inokulan N. oculata laboratorium Bioteknologi Balai Besar Riset

Tabel 1. Volume bak produksi fitoplankton dan rotifer di BBRPBL, Gondol

Table 1. Tank volume for phytoplankton and rotifer productions at the Research Institute for Mariculture, Gondol

\begin{tabular}{lcccc}
\hline \multirow{2}{*}{$\begin{array}{c}\text { Hatcheri } \\
\text { Hatchery }\end{array}$} & \multicolumn{2}{c}{$\begin{array}{c}\text { Fitoplankton } \\
\text { Phytoplankton }\left(\mathbf{m}^{\mathbf{3}}\right)\end{array}$} & \multicolumn{2}{c}{ Rotifer $\left(\mathbf{m}^{\mathbf{3}}\right)$} \\
\cline { 2 - 5 } & $\begin{array}{c}\text { Volume tanki } \\
\text { Tank volume }\end{array}$ & $\begin{array}{c}\text { Total } \\
\text { volume }\end{array}$ & $\begin{array}{c}\text { Volume tanki } \\
\text { Tank volume }\end{array}$ & $\begin{array}{c}\text { Total } \\
\text { volume }\end{array}$ \\
\hline MSP & $12,15,25^{*}$ & 134 & 3,6 & 21 \\
MSH & $15^{*}$ & 120 & 1.5 & 3 \\
Main & $10,20,50^{*}$ & 180 & 5,20 & 50 \\
\hline & & 434 & & 74 \\
\hline
\end{tabular}

Satu bak terbesar dipergunakan untuk menampung air laut steril

The biggest tank was used to store chlorinated sea water 
Tabel 2. Dosis pupuk produksi massal N. oculata

Table 2. Fertilizer dose for mass production of $\mathbf{N}$. oculata

\begin{tabular}{lccc}
\hline \multirow{2}{*}{$\begin{array}{c}\text { Pupuk } \\
\text { Fertilizer }\end{array}$} & \multicolumn{3}{c}{ Dosis (Dosage) $(\mathbf{m g} / \mathbf{L})$} \\
\cline { 2 - 4 } & BBRPBL & BBRPBL & BBRPBL \\
MSP & Main \\
\hline Urea & 60 & 80 & 50 \\
TSP & 50 & 40 & 40 \\
Na-EDTA & 15 & 10 & 30 \\
FeCl3 & 2 & 1 & 2 \\
Clewat-32 & 1 & 0.5 & 1 \\
\hline
\end{tabular}

Perikanan Budidaya Laut (BBRPBL) dan inokulan hasil produksi massal dari bak- bak fitoplankton outdoor lainnya dengan kepa-

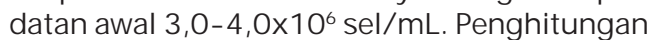
kepadatan harian fitoplankton dilakukan menurut Boyd \& Tucker (1992) dan Knuckey (Perscom). Setelah hari keenam, fitoplankton dipompa ke dalam bak- bak rotifer sebagai pakan rotifer atau dipindahkan ke dalam bakbak fitoplankton lainnya sebagai inokulan untuk produksi massal fitoplankton siklus berikutnya. Jika dijumpai kontaminan biotik dalam bak- bak fitoplankton (cilliates, protozoans dan rotifers), dilakukan sterilisasi dengan chlorin dosis $100 \mathrm{mg} / \mathrm{L}$ selama 30 menit kemudian dinetralisir dengan $50 \mathrm{mg} / \mathrm{L}$ sodium thiosulfat. Jika kontaminasi berlebihan yang membuat kepadatan fitoplankton menyusut atau mati maka proses produksi massal diulangi lagi dengan langkah- langkah di atas. Produksi massal fitoplankton dilakukan dengan sistem produksi semi-continuous system hingga 3- 4 siklus, bak kemudian dibersihkan, direndam dalam air klorin 100 mg/ L dan dikeringkan selama 1- 2 hari.

Pemadatan (flokulasi) fitoplankton pada masing- masing bak produksi dengan penambahan $\mathrm{NaOH}$ pada dosis $50 \mathrm{mg} / \mathrm{L}$, aerasi dihentikan dengan periode selama 20- 24 jam. Setelah padat dan tersedimentasi, fitoplankton tersebut disifon, ditampung dalam kontainer plastik dan disimpan dalam cold storage $\left(-12^{\circ} \mathrm{C}\right)$. Setelah penyimpanan selama $1-8$ minggu, fitoplankton tersebut dipergunakan sebagai pakan rotifer setelah diaerasi dengan laju 10- 15 L/ menit selama 24 jam.

Bak- bak fiberglass volume $0,5 \mathrm{~m}^{3} \mathrm{di}$ pergunakan dalam efisiensi produksi rotifer di dalam (indoor) dan di luar (outdoor) ruangan. Bak- bak tersebut diisi air laut yang dicampur dengan fitoplankton $N$. oculata kepadatan tinggi hasil flokulasi dengan kepadatan akhir $>1,0 \times 10^{8} \mathrm{sel} / \mathrm{mL}$ sedangkan rotifer ditebar pada masing- masing bak dengan kepadatan awal >100 ekor/mL. Pasok oksigen murni diberikan ke dalam setiap bak dengan laju 0,05-0.1 L/ menit. Setiap hari dilakukan penghitungan kepadatan rotifer dan fitoplankton. Fitoplankton ditambahkan pada hari ketiga, keenam, kesembilan dan ke- 12 setelah penebaran fitoplankton awal dengan kepadatan yang sama dengan kepadatan awal.

\section{Analisis Asam Lemak}

Rotifer dipanen total pada akhir setiap percobaan (hari ke-15) dengan saringan rotifer kemudian dikeringkan. Analisis lemak dan asam lemak rotifer yang diproduksi secara massal dan produksi pada percobaan ini dilakukan di Laboratorium Pusat Studi Pangan dan Gizi, Pusat Antar Universitas (PAU) Universitas Gadjah Mada Yogyakarta. Sedangkan ekstraksi lemak dilakukan di Laboratorium Kimia BBRPBL Gondol menurut metode Soxhlet. Analisis asam lemak dipergunakan GC 14 B Shimadzu dengan capilary column CBP10 sepanjang $50 \mathrm{~m}$. Suhu column $180^{\circ} \mathrm{C}-240^{\circ} \mathrm{C}$ dengan laju pemanasan $2.5^{\circ} \mathrm{C} /$ menit. Suhu injektor dan detector $250^{\circ} \mathrm{C}$ dengan gas Helium sebagai pembawa dengan tekanan 180 $\mathrm{kPa}$. Detektor yang dipergunakan adalah FID (Flame Ionization Detector) dengan integrator Shimadzu C- RGA. Larutan standar yang dipergunakan adalah Supelco ${ }^{\circledR}$ (U.S.A) Cat. \# 47801 dan Cat. \# 178241A (untuk EPA: 
eicosapetaenoic acid dan DHA: docosahexaenoic acid).

\section{Analisis Kualitas Air dan Data}

Pengukuran suhu, kelarutan oksigen (dissolved oxygen, DO), dan $\mathrm{pH}$ dilakukan dengan YSI DO dan pH meter sedangkan total ammonium dilakukan dengan metode spektrofotometer yang dilakukan setiap hari. Nilai pengamatan dalam kegiatan ini dicantumkan dalam rataan \pm standard error (SE) dengan analisis deskriptif dan pair-wise comparison (Sokal \& Rohlf, 1981). Perangkat lunak (software) komputer yang dipergunakan dalam analisis data dan pelaporan adalah Microsoft ${ }^{\oplus}$ Excel XP dan Microsoft ${ }^{\oplus}$ Word XP.

\section{HASIL DAN BAHASAN}

Hasil sampling penghitungan harian kepadatan rotifer dan fitoplankton efisiensi produksi rotifer didalam dan di luar ruangan dicantumkan dalam Gambar 1 (A, B, dan C). Ratarata kepadatan rotifer pada ketiga ulangan produksi di dalam ruangan berkisar antara 231259 ekor/mL dengan rata-rata kepadatan puncak yang berlangsung selama $2-3$ hari (hari ke- 7 sampai ke- 9) adalah $525 \pm 6,1$ ekor/ mL dengan kisaran kepadatan fitoplankton 2,1$12,6 \times 10^{8} \mathrm{sel} / \mathrm{mL}$. Rata- rata puncak kepadatan rotifer pada sistem produksi konvensional adalah 180 ekor/mL dengan kepadatan

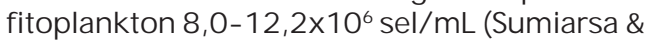
Setiadi, 2009) sehingga kepadatan puncak rotifer pada percobaan ini tiga kali lebih banyak dibandingkan dengan produksi rotifer secara konvensional. Produksi rotifer di luar ruangan pada percobaan ini hanya berlangsung selama 3- 4 hari dengan kepadatan rotifer dan fitoplankton yang terus menurun yang diduga disebabkan oleh kenaikan suhu air di dalam bak yang mencapai $34,1^{\circ} \mathrm{C}$ akibat dari penyerapan cahaya matahari oleh fitoplankton dengan kepadatan yang tinggi (Tabel 3).

Walaupun meningkat dibandingkan dengan produksi rotifer secara konvensional, rata- rata puncak kepadatan rotifer pada percobaan ini masih lebih rendah jika dibandingkan dengan kebutuhan untuk sebuah hatcheri. Kebutuhan harian rotifer untuk operasional hatcheri BBRPBL adalah sekitar 3,9 $\times 10^{9}$ ekor/ hari sehingga diperlukan sekitar 15 bak serupa yang dipanen setiap hari. Untuk memenuhi kekurangan tersebut, produksi pakan alami harus dilakukan dengan
A Indoor
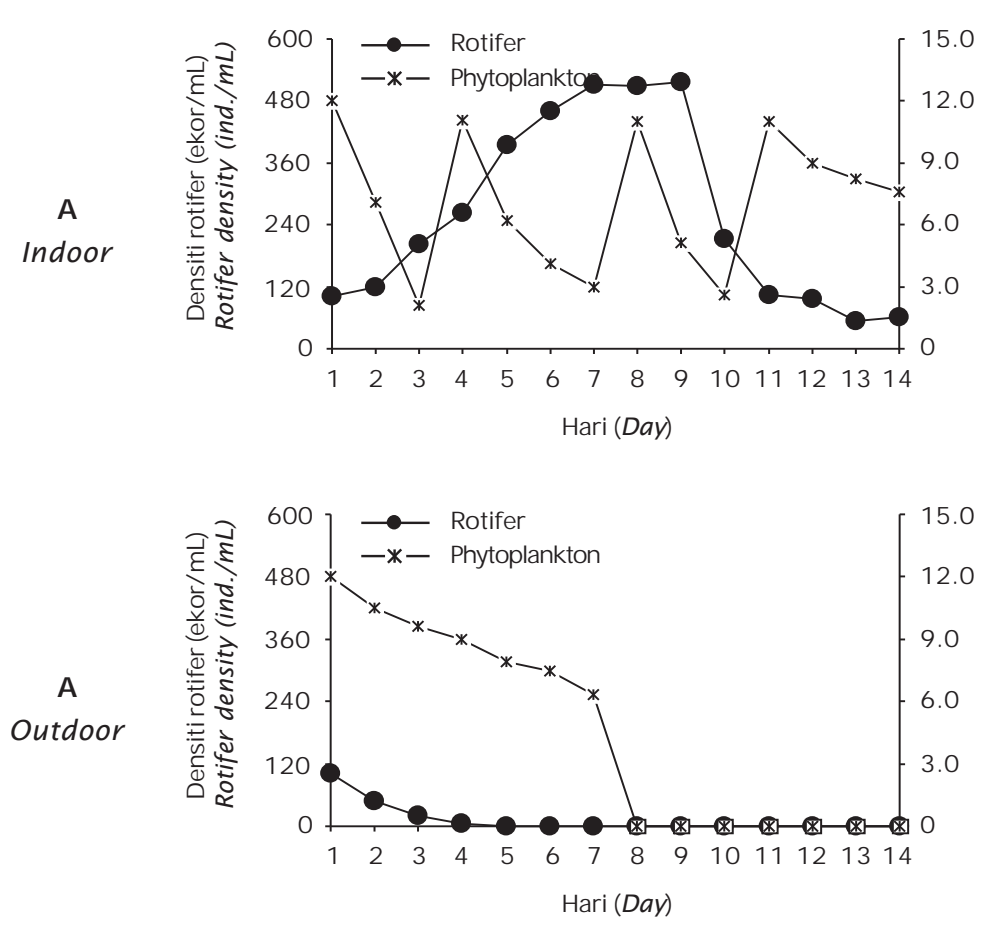
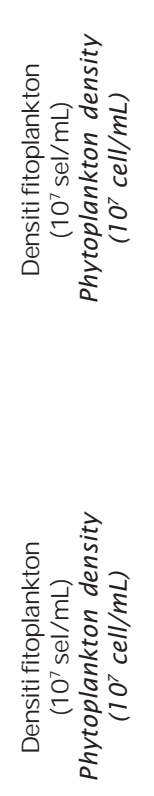
B

Indoor

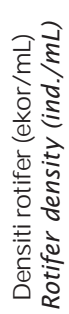

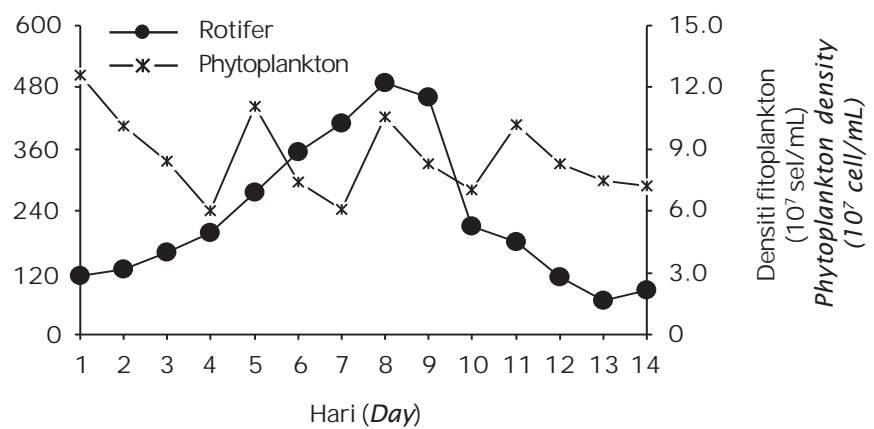

B
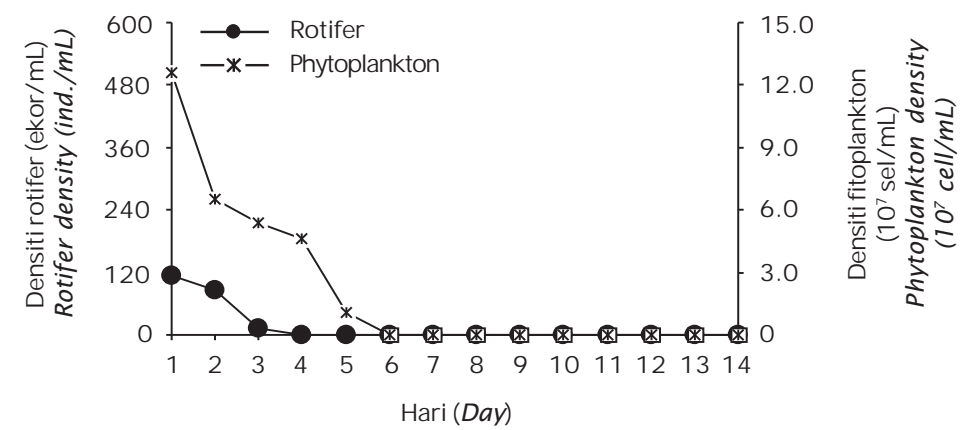

Outdoor

Hari (Day)
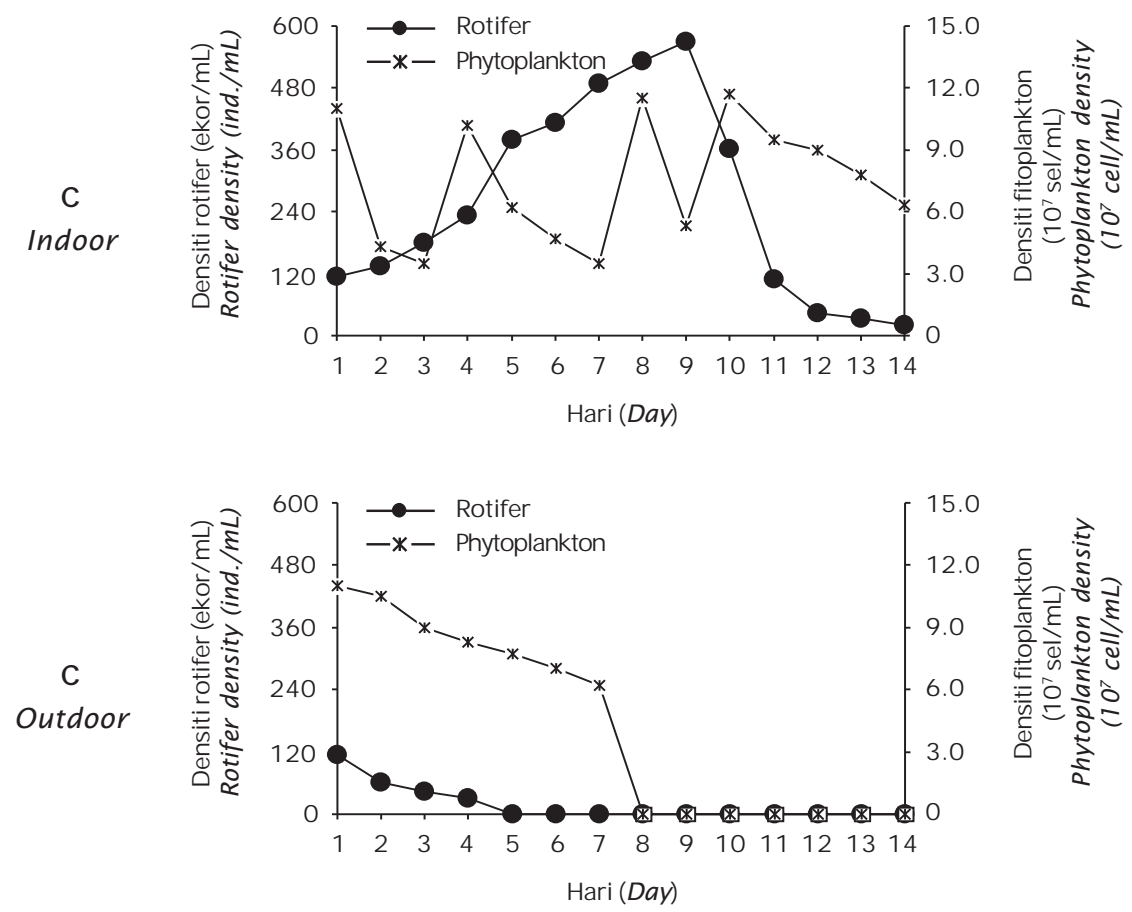

Gambar 1. Kepadatan harian rotifer dan fitoplankton pada tiga ulangan dalam bak- bak percobaan

Figure 1. Measured daily densities of rotifer and phytoplankton in the trial 
Tabel 3. Kisaran kualitas air pada percobaan di dalam dan di luar ruangan

Table 3. Ranges of water quality in indoor and outdoor trials

\begin{tabular}{lcc}
\hline \multicolumn{1}{c}{$\begin{array}{c}\text { Kualitas air } \\
\text { Water quality }\end{array}$} & $\begin{array}{c}\text { Di dalam ruangan } \\
\text { Indoor }\end{array}$ & $\begin{array}{c}\text { Di luar ruangan } \\
\text { Outdoor }\end{array}$ \\
\hline Kelarutan oksigen & $4.21-19.4$ & $6.38-17.10$ \\
Dissolved oxygen $(\mathrm{mg} / \mathrm{L})$ & $26.1-28.2$ & $26.7-34.1$ \\
Suhu (Temperature $)\left({ }^{\circ} \mathrm{C}\right)$ & $0.478-2.217$ & $0.655-1.114$ \\
Total ammonium $(\mathrm{mg} / \mathrm{L})$ & $8.3-8.7$ & $8.1-8.8$ \\
$\mathrm{pH}$ & & \\
\hline
\end{tabular}

dua alternatif yaitu mencapai rata- rata kepadatan harian tiga kali lebih tinggi (300\%) daripada rata- rata kepadatan saat ini atau produksi massal pakan alami dilakukan dalam kapasitas wadah produksi massal tiga kali lebih besar dengan rata- rata kepadatan harian yang sama. Alternatif kedua akan lebih sulit dilakukan sehingga hanya dapat diupayakan dengan alternatif pertama yaitu dengan peningkatan rata- rata kepadatan pakan alami harian yang dapat dicapai dengan sistem produksi seperti pada percobaan ini.

Produksi pakan alami secara massal dengan semi-continuous system outdoor memang memiliki beberapa kelemahan (Fulks \& Main, 1991; Okauchi, 1992) yaitu menghasilkan kepadatan yang relatif rendah dan kurang konsisten (unreliable) namun memiliki kelebihan yaitu murah, sederhana, dan tidak memerlukan teknisi yang terampil. Sebaliknya sistem produksi intensif indoor adalah mahal dan intensif tetapi dapat diandalkan (reliable) dengan kepadatan yang tinggi. Peningkatan produksi rotifer dapat dilakukan dengan pakan fitoplankton instant algae komersial kepadatan tinggi (Hirata, 1992; Soetanti et al., 2009) dan pemberian probiotik (Hino \& Maeda, 1992; Hirayama \& Ogihara, 1992; Pintado et al., 2010), penambahan bahan- bahan pengkaya (Tamaru \& Lee, 1991) atau dengan metode penyaringan khusus (Araujo \& Hagiwara, 2005) namun diperlukan kondisi-kondisi yang lebih spesifik untuk memenuhi sistem- sistem produksi pakan alami tersebut (Kongkeo, 1992).

Kelarutan oksigen yang tinggi disebabkan oleh penggunaan oksigen murni dalam percobaan ini dengan Iaju aliran 0,05-0,10 L/ menit. Kisaran total ammonium cukup tinggi, diperlukan upaya penurunan total ammonium dengan pemberian aerasi yang kuat sebelum rotifer diberikan kepada larva ikan. Tingginya kadar total ammonium dalam media produksi diduga dari kelebihan pupuk pertanian yang tidak seluruhnya terurai dan diserap sebagai hara oleh $N$. oculata dan akan berakibat negatif terhadap kualitas air laut pemeliharaan larvalarva ikan laut baik jika fitoplankton tersebut diperlukan secara langsung sebagai green water maupun secara tidak langsung melalui produksi massal rotifer. Total ammonium akan berubah menjadi amoniak yang tidak terionisasi $\mathrm{NH}_{3}$ (unionized ammonia) bergantung kepada suhu dan pH air (Boyd, 1990). Pemberian aerasi yang tinggi dan pembilasan hasil panen rotifer dengan baik sebelum diberikan kepada larva ikan akan mengurangi kandungan $\mathrm{NH}_{3}$. Sedangkan nilai $\mathrm{pH}$ cukup stabil dengan kisaran 8,1-8,8.

Hasil analisis asam lemak esensial, lemak dan protein rotifer pada percobaan ini dibandingkan dengan analisa rotifer pada produksi konvensional dicantumkan dalam Tabel 4.

Terlihat bahwa rotifer hanya dengan pemberian pakan fitoplankton $N$. oculata memiliki kandungan EPA yang tinggi namun minimal dalam kandungan DHA sehingga menghasilkan rasio DHA/EPA yang sangat rendah $(0,02)$. Untuk kebutuhan lemak dan profil asam lemak larva ikan-ikan laut, dibutuhkan kandungan lemak yang lebih tinggi dengan DHA/ EPA rasio mendekati 2,0 (Sargent et al., 1997), oleh sebab itu rotifer hasil produksi masal dalam percobaan ini mutlak diperkaya (enriched) dengan bahan- bahan pengkaya komersial (Sargent et al., 1999).

Biaya produksi rotifer secara konvensional (tidak termasuk tenaga kerja dan listrik) adalah Rp. 49,- / juta rotifer sedangkan biaya produksi rotifer dalam percobaan ini dengan 
Tabel 4. Asam lemak esensial, lemak dan protein rotifer pada produksi konvensional dan percobaan

Table 4. Essential fatty acid, lipid and protein contents of rotifer in conventional production compared with the trial

\begin{tabular}{lcc}
\hline $\begin{array}{c}\text { Asam lemak } \\
\text { Fat acid } \\
\text { (mg/g DW) }\end{array}$ & \multicolumn{2}{c}{ Sistem produksi (Production system ) } \\
\cline { 2 - 3 } & $\begin{array}{c}\text { Konvensional } \\
\text { Convensional }\end{array}$ & $\begin{array}{c}\text { Percobaan } \\
\text { Trial }\end{array}$ \\
\hline 20:5n-3 (EPA) & $35.1^{\mathrm{a}}$ & $57.2^{\mathrm{b}}$ \\
$22: 6 \mathrm{n}-3$ (DHA) & - & 1.4 \\
DHA/ EPA & - & 0.02 \\
Total n-3 HUFA & $42.2^{\mathrm{a}}$ & $61.5^{\mathrm{b}}$ \\
Lemak (Fat) & $10.8^{\mathrm{a}}$ & $14.0^{\mathrm{b}}$ \\
Protein (Protein) & $55.6^{\mathrm{a}}$ & $56.4^{\mathrm{a}}$ \\
\hline
\end{tabular}

* Nilai- nilai yang diikuti huruf sama pada setiap baris adalah tidak berbeda nyata (Values followed by the same superscript in each row are not significantly different $(\mathrm{P}>0.05)$ )

fitoplankton flokulasi adalah Rp. 51,- / juta rotifer sehingga efisiensi cukup tinggi yaitu kelebihan biaya produksi Rp. 2,- / juta rotifer $(4,1 \%$ dapat menghasilkan kepadatan rotifer tiga kali lebih tinggi (300\%). Biaya produksi rotifer dengan menggunakan alga instan (Nanno- 3600) lebih tinggi yaitu Rp. 1.946,- / juta rotifer. Namun hingga saat ini pemakaian instant algae kepadatan tinggi secara intensif masih terbatas penggunaannya dalam hatcheri ikan- ikan laut di Indonesia yang disebabkan oleh harganya yang mahal dan prosedur impor yang memerlukan waktu yang relatif lama.

\section{KESIMPULAN}

1. Produksi pakan alami rotifer ( $B$. rotundiformis) dengan pakan fitoplankton N. oculata BBRPBL pada tahun 2009 dilakukan dengan sistem produksi semicontinuous di luar ruangan (outdoor) dengan rata- berkepadatan tinggi hanya dapat dilakukan di dalam ruangan (indoor).

2. Efisiensi produksi rotifer kepadatan tinggi dengan pakan flokulasi fitoplankton lebih tinggi dibandingkan dengan efisiensi produksi rotifer secara konvensional sedangkan efisiensi produksi rotifer dengan pakan fioplankton alga instan sangat rendah.

3. Untuk meningkatkan kehandalan produksi rotifer, diperlukan produksi dan panen harian rotifer yang tidak terputus agar dapat menyediakan rotifer secara terusmenerus.

\section{DAFTAR ACUAN}

Araujo, A., Hagiwara, A., \& Snell, T.W. 2001. Effect of unionized ammonia, viscosity and protozoan contamination on reproduction and enzyme activity of the rotifer Brachionus rotundiformis. Hydrobiologia, (446- 447)1: 363- 368.

Araujo, A. \&Hagiwara, A. 2005. Screening methods for improving rotifer culture quality. Development in Hydrobiology, (181)9: 553558.

Boyd, C.E. 1990. Water quality in ponds for aquaculture. Alabama Agricultural Experiment Station Auburn University, Alabama.

Boyd, C.E. \& Tucker, C.S. 1992. Water quality and pond soil analyses for aquaculture. Alabama Agricultural Experiment Station. Auburn University, Alabama, USA, 183 pp.

Craig, S.R., Arnold, C.R., \& Holt, G.J. 1994. The effects of enriching live foods with highly unsaturated fatty acids on the growth and fatty acid composition of larval red drum Sciaenops ocellatus. Journal of World Aquaculture Society, 25:424- 431.

Fukusho, K. \& Hirayama, K. 1991. The first live feed - Brachionus plicatilis. The Oceanic Institute, Hawaii, U.S.A., 144 pp.

Fulks, W. \& Main, K.L. 1992. Rotifer and microalgae culture systems. Proceeding of a U.S. - Asia Workshop. The Oceanic Institute of Hawaii, U.S.A, 348 pp.

Hino, A. \& Maeda, M. 1992. Control of the biological environment. In Fukusho, K. and K. 
Hirayama (Eds.). The first live feedBrachionus plicatilis. The Oceanic Institute, p. 137- 141.

Hirata, I. 1992. Large- scale culturing of highquality Chlorella. In Fukusho, K. and K. Hirayama (Eds.). The first live feedBrachionus plicatilis. The Oceanic Institute, p. 111- 118.

Hirayama, K. \& Ogihara, A. 1992. In Fukusho, K. and K. Hirayama (Eds.). The first live feedBrachionus plicatilis. The Oceanic Institute p. $132-136$.

Kongkeo, H. 1991. An overview of live feed production system design in Thailand. In: Fulks, W., and K. L. Main. 1991. Rotifer and microalgae culture systems. Proceeding of a U.S. - Asia Workshop. The Oceanic Institute of Hawaii, U.S.A, p. 175- 186.

Okauchi, M. 1992. Large- scale cultivation methods for microalgal feeds. In Fukusho, K. and K. Hirayama (Eds.). The first live feedBrachionus plicatilis. The Oceanic Institute, p. 49- 74.

Pintado, J., Perez- Lorenzo, M., Luna- Gonzalez, A., \& Sotelo, C.G. 2010. Monitoring of the bioencapsulation of a probiotic Phaeobacter strain in the rotifer Brachionus plicatilis using denaturing gradient gel electrophoresis. Aquaculture, 302: 182- 194.

Sargent, J., McEvoy, L.A., \& Bell, J.G. 1997. Requirements, presentation and sources of polyunsaturated fatty acids in marine fish larval feeds. Aquaculture, 155: 117- 127.

Sargent, J., McEvoy, L., Estevez, A., Bell, G., Bell, M., Henderson, R.J., \& Tocher, D. R. 1999. Lipid nutrition of marine fish during early development: current status and future directions. Aquaculture, 179: 217- 229.

Soetanti, E., Gafur, A., Syukri, M., \& Haeruddin. 2009. Upaya peningkatan kultur rotifer densitas tinggi melalui suspensi alga sistem resirkulasi sederhana. BBAP Takalar (In press).

Sokal, R.R. \& Rohlf, F.J. 1981. Biometry. W.H. Freeman, New York, U.S.A.

Su, H.M., Su, M.S., \& Liao, I.C. 1997. Preliminary results of providing various combinations of live foods to grouper (Epinephelus coioides) larvae. Hydrobiologia, 358: 301304.

Sumiarsa, G.S. \& Setyadi, I. 2009. Perbaikan teknik produksi masal pakan alami untuk mendukung perbenihan ikan laut. Laporan Hasil Penelitian BBRPBL 2009, 16 hlm.

Tamaru, C. \& Lee, C.- S. 1991. Improving the larval rearing of striped mullet (Mugil cephalus) by manipulating quantity and quality of the rotifer, Brachionus plicatilis. In: Fulks, W., and K. L. Main. 1991. Rotifer and microalgae culture systems. Proceeding of a U.S. - Asia Workshop. The Oceanic Institute of Hawaii, U.S.A., p. 89- 104.

Witt, U., Quantz, G., Kuhlmann, D., \& Kattner, G. 1984. Survival and growth of turbot larvae Scophthalmus maximus $L$. reared on different food organisms with special regard to long- chain polyunsaturated fatty acids. Aquacultural Engineering, 3: 177- 190.

Yoshida, M. 1992. Types of large- scale culturing methods. In: Fukusho, K., and K. Hirayama (Eds.). 1992. The first live feed Brachionus plicatilis. The Oceanic Institute, Hawaii, U.S.A., 144 pp. 